\title{
Peptides regulating gastrointestinal function in children before and after hematopoietic stem cell transplantation
}

Magdalena Rej ( $\square$ rej.magdalena@gmail.com )

Uniwersytet Jagiellonski w Krakowie Collegium Medicum https://orcid.org/0000-0002-2305-8227

Szymon Skoczeń

Uniwersytet Jagiellonski w Krakowie Collegium Medicum

Danuta Pietrys

Uniwersytecki Szpital Dziecięcy w Krakowie

Kinga Kwiecińska

Uniwersytet Jagiellonski w Krakowie Collegium Medicum

Przemysław J. Tomasik

Uniwersytet Jagiellonski w Krakowie Collegium Medicum

Małgorzata Wójcik

Uniwersytet Jagiellonski w Krakowie Collegium Medicum

Wojciech Strojny

Uniwersytecki Szpital Dziecięcy w Krakowie

Agnieszka Dłużniewska

Uniwersytecki Szpital Dziecięcy w Krakowie

Katarzyna Klimasz

Uniwersytecki Szpital Dziecięcy w Krakowie

Kamil Fijorek

Uniwersytet Ekonomiczny w Krakowie

Michał Korostyński

Polska Akademia Nauk Odzial w Krakowie

Marcin Piechota

Polska Akademia Nauk Odzial w Krakowie

Walentyna Balwierz

Uniwersytet Jagiellonski w Krakowie Collegium Medicum

Research article

Keywords: hematopoietic stem cell transplantation, peptides regulating gastrointestinal tract functions, children 
Posted Date: November 1st, 2019

DOl: https://doi.org/10.21203/rs.2.16711/v1

License: (c) (i) This work is licensed under a Creative Commons Attribution 4.0 International License. Read Full License 


\section{Abstract}

Gastrointestinal tract function and it's integrity are controlled by a number of peptides whose secretion is influenced by severe inflammation. In stomach the main regulatory peptide is ghrelin. For upper small intestine cholecystokinin and glucagon-like peptide- 1 are secreted, while fibroblast growth factor-21 is secreted by several organs, including the liver, pancreas, and adipose tissue [12]. Hematopoietic stem cell transplantation causes serious mucosal damage, which can reflect on this peptides. The aim of the study was to determine fasting plasma concentrations of ghrelin, cholecystokinin, glucagone- like peptide-1, and fibroblast growth factor -21, and their gene expressions, before and 6 months after hematopoietic stem cell transplantation. 27 children were studied. C ontrol group included 26 healthy children. Acute graft versus host disease was diagnosed in 11 patients $(41 \%, n=27)$. Median pre-transplantation concentrations of ghrelin, cholecystokinin, and glucagone like peptide-1, as well as their gene expressions, were significantly lower compared with the control group. In contrast, median fibroblast growth factor-21 concentrations were near-significantly higher before stem cell transplantation than in the control group. A comparison of pre- and post-transplantation groups revealed significantly higher concentrations of the studied peptides (except fibroblast growth factor-21) and respective gene expressions in the post-hematopoietic transplant group. M edian glucagone like peptide-1 concentrations were significantly decreased in patients with features of acute graft versus host disease. Moreover, negative correlation between glucagone like peptide-1 concentrations and acute graft versus host disease severity was found. Increased concentrations and gene expressions of gastrointestinal tract regulation peptides can be caused by stimulation of regeneration in the severe injured organ.

Measurement of these parameters may be a useful method of assessment of severity of gastrointestinal tract complications of hematopoietic stem cell transplantation.

\section{Background}

Impaired intestinal function is a common complication of hematopoietic stem cell transplantation (HSCT). Damage to the gastrointestinal (GI) mucosa in patients undergoing HSCT is a serious but still poorly understood complication. Toxicity of HSCT conditioning regimens and graft-versus-host disease (GvHD) result in a 5-fold increase of the risk of significant GI complications compared with other cancer survivors [1,2]. Chemotherapy and total body irradiation (TBI) can damage $\mathrm{GI}$ mucosa and cause diffuse inflammation of GI tract. This leads to disruption of integrity of GI mucosa with subsequent transfer of bacterial lipopolysaccharides and other danger/pathogen-associated molecular patterns (DAMPs/PAMPs) into the systemic circulation [3].

The intestine is also known as the largest endocrine organ in the body. It strongly influences other organs, including the brain via the gut-brain axis [4]. The majority of GI regulatory peptides are secreted by strictly defined sections of the intestine [5]. Ghrelin is produced mainly in the stomach by P/D1 cells, cholecystokinin (CCK) is secreted mainly by the I cells of the upper small intestine, while glucagone like peptide-1 (GLP-1) is produced by the endocrine $L$ cells in the lower intestine $[6,7,8,9,10,11]$. Fibroblast 
growth factor-21 (FGF21) is secreted by several organs, including the liver, pancreas, and adipose tissue [12].

The intensity of GI dysfunction can be assessed using mucositis grading and parenteral nutrition requirements, but these tools cannot identify the most severely affected parts of the GI tract [13]. Endoscopy is rarely performed in the early post-HSCT phase due to the high risk of severe complications. In addition, the test load with nutrients is unreliable in this phase. Due to the differences in the anatomic distribution of intestinal endocrine cells, studies of alterations in GI peptide concentrations might help to localize the affected sections of the gut and assess the severity of inflammation. Thus, there is a need to identify simple and noninvasive tests that can assess the location and severity of gut damage. Additional comparison of marker concentrations before and several months after HSCT can explain the mechanisms of destruction and restoration of the GI tract $[14,15,16]$. The aim of this study was to determine and analyze the selected GI peptides secreted on different levels of the gut in patients before and after HSCT.

\section{Methods}

\section{$\underline{\text { Study_groups }}$}

A group of 27 children aged 1.5 - 19 years (median 9.6 years) was referred to the Stem Cell

Transplantation Centre of the University Children's Hospital in Krakow and was included in this study. The patients were assessed twice-before HSCT (pre-HSCT group) and approximately 6 months after HSCT (post-HSCT group). Diseases that were the indication for HSCT are listed in Table 1. Patients with malignancies, except for juvenile myelomonocytic leukemia (JMML), were referred for HSCT in complete remission. Characteristics of the transplantation procedures are detailed in Table 2.

In more than half of the patients ( 16 patients, $n=27$ ) a conditioning regimen was based on busulfan/treosulfan. Total body irradiation (TBI) was used in 7 of patients. Most patients (85\%) in whom graft-versus-host disease (GvHD) prophylaxis was used received methotrexate combined with cyclosporine. Mucositis was diagnosed in $82 \%$ cases (22 patients), grade III and IV mucositis in $26 \%$ (7 patients). The key clinical data of the HSCT recipients are presented in Table 3. Mucositis requiring parenteral nutrition was found in almost half $(48 \%)$ of the patients. Systemic glucocorticoids were used in 19 children in the post-HSCT group to treat complications of HSCT. In 11 of patients aGvHD was seen, including intestinal involvement in one. According to the aGvHD grader (agvhd.com), grade II and III aGvHD was found in $22 \%$ cases ( 6 patients). In two cases multiple locations of aGvHD occurred (II/C skin+liver, III/C - skin+Gl+liver). The patients with aGvHD were treated with additional immunosuppressive agents, including tacrolimus, mycophenolate mofetil, and etanercept. Six months after HSCT, four children still received tapered doses of immunosuppressive agents other than glucocorticoids. The control group consisted of 11 boys and 15 girls aged 4.3 to 16.0 years (median 12.2 years). The control children were recruited among family donors, siblings of patients treated with HSCT, and unrelated 
healthy children. They all had negative medical history, no signs or symptoms of acute or chronic diseases, and no abnormalities in laboratory tests (CBC, serum ALT, and creatinine levels).

\section{Anthropometric measurements}

Height and body weight measurements were performed by an anthropometrist. Body mass index (BMI), BMI percentile (BMIPerc) and BMI SDS (BMISDS) were calculated using online WHO BMI calculators [17]. The results were compared to regional reference values, and the reference values were published by the WHO $[18,19,17]$. The BF mass and $\mathrm{BF} \%$ were measured using bioimpedance and calculated according to the method described by Kushner RF and Schoeller DA [20].

\section{Study_protocol}

Fasting blood samples were collected in the morning. Patients treated with HSCT were assessed immediately before conditioning and after a median of 6.3 months after HSCT. In the control group samples were obtained once, after enrollment to the study. Blood samples were collected in EDTA and aprotinin tubes, (Becton-Dickinson; UK), and tubes with no anticoagulants. The tubes were delivered to the laboratory immediately and centrifuged for 15 minutes at 3000 rpm using a horizontal rotor. Serum and plasma samples were stored at $-80^{\circ} \mathrm{C}$ until the time of measurement. Subsequently, mononuclear cells were separated for microarray followed by total RNA extraction.

\section{Laboratory measurements}

Plasma concentrations of the peptides were measured using the following assays: ghrelin, CCK, GLP-1EIA (Phoenix Pharmaceuticals, Inc., USA), and FGF-21-EIA (Millipore Corporation USA).

\section{Microarray analysis}

Microarray analysis used a GeneChip Human Gene 1.0 ST Arrays (Affimetrix, Santa Clara, USA) according to the manufacturer's protocol. GLP-1 expression data were not available in the Affimetix database, and thus we checked the results of GLP-1 receptor gene expression. Gene loci and Affimetrix codes of the tested peptides are presented in Table 4.

All the primary microarray data were submitted to GEO public repository and are accessible using GEO Series accession number GSE69421 (http://www.ncbi.nlm.nih.gov/geo/query/acc.cgi?acc=GSE32472). In our study a part of submitted microarray data was used.

\section{Declatarions}

Micoarray analisis data is available in public repository. Biochemical data is available on author request. Statistical analysis 
Continuous clinical and biochemical variables are presented as the mean values and standard error or as the median values and quartiles, as appropriate. Categorical variables are presented as frequencies and percentages. The Shapiro-Wilk test was used to assess the normal distribution of the continuous variables. To examine the differences between two or more independent groups, ANOVA/Student's t-test (for variables with normal distribution) or Kruskal-Wallis/Mann-Whitney tests (for variables with nonnormal distribution) were used. To examine the differences between two dependent groups, Student's ttest for paired samples (for variables with normal distribution) or Wilcoxon signed-rank test (for variables with non-normal distribution) were used. To assess the correlations between two continuous variables, Spearman rank correlation coefficient was calculated. The two-sided p-values $<0.05$ were considered statistically significant.

Gene expression data were RMA-normalized and presented as the mean and standard deviation. ANOVA was used to examine the differences in gene expression between two independent groups. The Benjamini-Hochberg $(\mathrm{B}-\mathrm{H})$-corrected $\mathrm{p}$-values $<0.05$ were considered statistically significant. The statistical analyses were performed using the R 3.4 .3 software.

\section{Ethics approval and consent to participats}

The Permanent Ethical Committee for Clinical Studies of the Medical College of the Jagiellonian University approved the study protocol. All parents, adolescent patients, and adult patients signed a written informed consent before blood sample collection. Study was conducted in accordance with the Declaration of Helsinki.

\section{Consent for publication}

Not applicable

\section{Results}

When comparing the pre-HSCT and post-HSCT groups and the control group (Table 5), we noted a significantly lower BF mass and BF\% measured using bioimpedance $(6.46 / 12.0 ; 6.65 / 12.0, p<0.05)$. The comparative analysis of the pre-HSCT group and the post-HSCT group showed no significant differences in anthropometric parameters.

\section{Ghrelin}

The median ghrelin concentrations in the pre-HSCT group (median $501 \mathrm{pg} / \mathrm{ml}$ [first and third quartile $425 ; 582])$ and in post-HSCT group (558 pg/ml [445;701]) were significantly lower compared with the median concentration in the control group $(711 \mathrm{pg} / \mathrm{ml}[596 ; 898])(p<0.001$ and $p=0.05$, respectively). Differences in ghrelin concentrations between the pre-HSCT and post-HSCT groups were statistically significant $(p=0.016)$ (Figure 1). Statistical analysis also revealed a considerable trend towards 
significance $(p=0.08)$ for the decreased ghrelin concentrations in patients with mucositis. Interestingly, ghrelin levels were increased in patients with liver aGvHD comparing with those with cutaneous and intestinal aGvHD $(p=0.02)$.

Analysis of ghrelin gene expression revealed near-significantly $(p=0.07)$ lower $(6.84+/-0.41$ vs. $6.99+/-0.25$ ) values in the post-HSCT group compared with the control group (Benjamini-Hochberg corrected p-value $(B-H)=0.09$; Table 4).

\section{Cholecystokinin}

Median CCK concentration in the pre-HSCT group $(1.23 \mathrm{ng} / \mathrm{ml}$; [first and third quartile $0.88 ; 1.70])$ was significantly lower than in the post-HSCT group $(2.32 \mathrm{ng} / \mathrm{ml}[1.42 ; 6.58] ; p<0.005)$ and in the control group $(3.46 \mathrm{ng} / \mathrm{ml}[2.87 ; 5.12] ; \mathrm{p}<0.001)$. CCK concentrations in the post-HSCT group and control group showed no significantly differences (Figure 1). The analysis of CCK gene expression revealed that mean CCK gene expression was significantly $(p=0.0014, B-H=0.03)$ lower $(5.61+/-0.14$ vs. $5.89+/-0.23)$ in the postHSCT group than in the control group (Table 4).

\section{Glucagon like peptide-1}

The lowest median GLP-1 concentrations were seen in the pre-HSCT group $(0.62 \mathrm{ng} / \mathrm{ml}$ [first and third quartile $0.47 ; 0.90]$. The values observed in the post-HSCT group $(1.31 \mathrm{ng} / \mathrm{ml}[0.83 ; 1.82])$ and in the control group were not significantly different $(1.26 \mathrm{ng} / \mathrm{ml}[1.14 ; 1.56])$. The differences between the preHSCT group and the post-HSCT group, as well as between the pre-HSCT group and the control group, were significant $(p<0.003, p<0.001$ respectively; Figure 1$)$.

Median concentration of GLP-1 was significantly decreased in patients with aGvHD symptoms $(p=0.008)$. Moreover, GLP-1 levels negatively correlated with grade of aGvHD ( $r=-0.58)$. Logistic regression model indicates that GLP-1 concentration may be a potential biomarker of aGvHD progression $(p=0.03)$.

GLP-1 receptor gene expression revealed a significantly lower mean expression (6.26+/-0.08 vs. $6.61+/-0.27)$ in the post-HSCT group compared with the control group $(\mathrm{p}=0.000, \mathrm{~B}-\mathrm{H}=0.0001$; Table 4).

\section{Fibroblast growth factor-21}

Median FGF-21 concentrations seen in the pre-HSCT group (146 pg/ml; [first and third quartile 83.9; 303]) were higher than in the post-HSCT group $(64.8 \mathrm{pg} / \mathrm{ml}[45.9 ; 135] ; \mathrm{p}=0.024)$ and in the control group (65.3 $\mathrm{pg} / \mathrm{ml}[51.9 ; 115] ; p=0.068)$. Analysis of FGF-21 gene expression revealed that its mean expression was significantly lower $(5.36+/-0.12$ vs. $5.59+/-0.16, p=0.0009, B-H=0.0021)$ in the post-HSCT group than in the control group (Table 4).

No significant correlations between conditioning intensity or severity of mucositis grade and the studied peptide concentrations were found. No significant differences in the peptide levels were found between group with chemotherapy with Busulfan or Cyclophosphamide and TBI (Figure 2). 


\section{Discussion}

Conditioning regimens are highly toxic to $\mathrm{GI}$ mucosal cells. The damage to the $\mathrm{GI}$ tract as well as other organs causes adverse effects, like nausea, vomiting, or diarrhea [21]. Clinical symptoms are well described, but there are no precise markers of advanced intestinal involvement and/or recovery. Endoscopic evaluation and intestinal biopsy are not recommended in patients with acute disease due the high risk of bleeding from seriously damaged mucosa and perforation. Therefore, there is a need to define blood biomarker that would correlate with location and severity of mucositis. Recently, serum citrulline (a non-essential amino acid) was proposed as a biomarker of small intestinal enterocyte mass and function $[22,23]$. Citrulline indicates damage to the small intestine but is not specific to the intestinal enterocytes, because it is also produced in hepatocytes [24]. Therefore, we looked for other possible markers of GI mucositis dedicated to various levels of the gut. We studied concentrations of ghrelin produced in the stomach, CCK produced in the jejunum, GLP-1 produced in the ileum, and FGF-21 produced in the liver, pancreas, and white and brown adipose tissue $[25,26]$.

The amount of body fat did not influence peptide secretion, as the HSCT subgroups did not differ in terms of anthropometric parameters. Our study showed that 6 months after conditioning there was a significant increase in the secretion of ghrelin, CCK, and GLP-1. Plasma concentrations of these peptides were lower in the pre-HSCT group than the post-HSCT (convalescent) group and the control group. Kuruca et al. showed that irradiation during the treatment of intestinal cancers was associated with a decrease in ghrelin concentrations [27]. The low concentrations of ghrelin persisted 3 months after irradiation. Statistical analysis of our data revealed a considerable trend towards significance $(p=0.08)$ for the decreased ghrelin concentrations in patients with mucositis. Moreover, we found that 6 months after irradiation patients had higher levels of ghrelin compared to the values before conditioning. This suggests recovery of ghrelin secretion. This is favorable because ghrelin reduces intestinal injury and mortality after irradiation in animal models [28]. Interestingly, ghrelin levels were increased in patients with liver aGvHD compared with those with cutaneous or intestinal aGvHD $(p=0.02)$. This suggests dysregulation of gastric peptide secretion caused by liver damage.

CCK has anti-inflammatory properties and reduces cell apoptosis [29, 30]. We found higher concentrations of CCK after HSCT suggesting regeneration of the upper small intestine. The median concentration of GLP-1 was significantly decreased in patients with aGvHD symptoms. Moreover, GLP-1 levels negatively correlated with severity of aGvHD. In addition, GLP-1 concentrations returned to baseline (the values seen in healthy subjects) six months after conditioning. This suggests full recovery of the ileum. Logistic regression model indicates that GLP-1 concentration could be a potential biomarker for progression of aGvHD.

Increased concentrations of FGF-21 before conditioning suggest that hepatic injury may result from prolonged chemotherapy administered before HSCT. Animal models show that liver damage induces FGF-21 expression [31]. Conditioning adds to an additional liver injury. FGF-21is recognized as a stress response hepatokine that reduces hepatic damage through increased glucose uptake by adipose tissue. 
Normalization of FGF-21 concentrations 6 months after HSCT suggests complete recovery of hepatic function after transplantation. The FGF-21 gene expression data confirm the findings from biochemical analysis.

\section{Conclusions}

Conditioning before HSCT and GvHD result in a widespread damage to the GI tract. Our data reveal that the stomach, jejunum, ileum, and liver are affected by chemo- and radiotherapy. Ghrelin may be a biomarker for liver aGvHD, and GLP-1 seems to be a potential biomarker for the progression of aGvHD. The increases in the concentrations of the regulatory peptides secreted in all parts of the GI tract suggest intensive regeneration of the mucosa. These alterations seem to be beneficial. The peptide measurements allow us to monitor intestinal damage and regeneration. Our study also showed that dysregulation of peptide secretion in some segments of the intestine are long-lasting, as 6 months after HSCT increased ghrelin secretion in the stomach, as well as CCK secretion in the jejunum, did not return to the values seen in the control group. The gene expression data are consistent with the biochemical data.

\section{Abbreviations}

ALT- alanine transaminase, aGvHD- acute graft-versus- host disease, BF- body fat, BMI- body mass index, BMIPerc- BMI percentile, BMISDS- BMI standardised, CBC- complete blood count, EIA- enzyme immunoassay, FGF21- Fibroblast growth factor-21, CCK- cholecystokinin, Gl- gastrointestional tract, GLP1-glucagone like peptide-1, GvHD- graft-versus- host disease, HSCT- hematopoietic stem cell transplantation, JMML- juvenile myelomonocytic leukemia, TBI- total body irradiation

\section{Declarations}

\section{Competing intrests:}

Authors declare that they have no competing interests

\section{Funding}

This work was supported by the National Science Centre under grant number NN 407198737

\section{Acknowledgements and Authors' contributions:}

Szymon Skoczeń - Concept/design, Data collection, Data analysis/interpretation, Drafting article, Critical revision of article. Danuta Pietrys, Magdalena Rej, Kinga Kwiecińska - Data analysis/interpretation, Drafting article. Przemysław Tomasik, Katarzyna Klimasz- biochemical analysis. Agnieszka Dłużniewska,Wojciech Strojny, Małgorzata Wójcik- Critical revision of article. Kamil Fijorek, Marcin Korostynski, Marcin Piechota - Data analysis/interpretation. Walentyna Balwierz, Szymon Skoczeń supervised the study. 


\section{References}

1. Ghimire S, Weber D, Mavin E, Wang XN, Dickinson AM, Holler E. Pathophysiology of GvHD and Other HSCT-Related Major Complications. Front Immunol 2017; 8: 79.

2. Armenian SH, Sun CL, Kawashima T, Arora M, Leisenring W, Sklar CA, et al. Long-term health-related outcomes in survivors of childhood cancer treated with HSCT versus conventional therapy: a report from the Bone Marrow Transplant Survivor Study (BMTSS) and Childhood Cancer Survivor Study (CCSS). Blood 2011; 4: 1413-20.

3. Markey KA, MacDonald KP, Hill GR. The biology of graft-versus-host disease: experimental systems instructing clinical practice. Blood 2014; 17: 354-62.

4. H. Ahlman, O. Nilsson. The gut as the largest endocrine organ in the body. Ann Oncology 2001;12 (suppl 2): S63-8.

5. Moran TH. Gut peptides in the control of food intake. Int J Obes (Lond) 2009; 33 (suppl 1): S7-10.

6. Date Y, Kojima M, Hosoda H, Sawaguchi A, Mondal MS, Suganuma T, et al. Ghrelin, a novel growth hormone-releasing acylatedpeptide, is synthesized in a distinct endocrine cell type in the gastrointestinal tracts of rats and humans. Endocrinology 2000; 141: 4255-4256.

7. Gualillo O, Caminos J., Blanco M, Garcia-Caballero T, Kojima M, Kangawa K, et al. Ghrelin, a novel placental-derived hormone. Endocrinology 2001; 142: 788-794.

8. Burckhardt B, Delco F, Ensinck JW, Meier R., Bauerfeind P, Aufderhaar J, et al. Cholecystokinin is a physiological regulator of gastric acid secretion in man. Eur $\mathrm{J}$ Clin Invest 1994; 24: 370-376.

9. Liddle RA, Goldfine ID, Rosen MS, Taplitz RA, Williams JA. Cholecystokinin bioactivity in human plasma. Molecular forms, responses to feeding, and relationship to gallbalder contraction. $\mathrm{J}$ Clin Invest 1985; 75: 1144-1152.

10. Fehmann HC, Goke R, Goke B. Cell and molecular biology of the incretin hormones glucagon-like peptide-l and glucose-dependent insulin releasing polypeptide. Endocrine Reviews 1995; 15: 390-407.

11. George SK, Uttenthal LO, Ghiglione M, Bloom SR. Molecular forms of glucagon like peptides in man. FEBS Lett 1985; 192: 275-278.

12. Iglesias P, Selgas R, Romero S, Díez J. Biological role, clinical significance, and therapeutic possibilities of the recently discovered metabolic hormone fibroblastic growth factor 21 . Eur $\mathrm{J}$ Endocrinol 2012;167: 301-309. 
14. Date $Y$, Nakazato M, Hashiguchi S, Dezaki K, Mondal MS, Hosoda H, et al. Ghrelin is present in pancreatic alpha-cells of humans and rats and stimulates insulin secretion. Diabetes 2002; 5: 124-129.

15. Douglas $B R$, Woutersen RA, Jansen JB, de Jong AJ, Lamers $C B$. The influence of different nutriens on plasma cholecystokinin levels in rat. Experientia 1988; 44: 21-23.

16. Wren AM, Seal LJ, Cohen MA, Brynes AE, Frost GS, Murphy KG, et al. Ghrelin enhances appetite and increases food intake in humans. J ClinEndocrinolMetab 2001; 86: 5992-5995.

17. WHO Anthro (version 3.2.2, January 2011) and macros [https://www.who.int/childgrowth/software/en/]

18. Gołąb S, Chrzanowska M. Child of Krakow region 2000. Biological development of children and adolescents in Krakow city. Poziom rozwoju biologicznego dzieci i młodzieży miasta Krakowa. Studia i Monografie AWF w Krakowie 2000: 19

19. Palczewska I, Niedźwiecka Z. Indices of somatic development of Warsaw children and adolescents. (Wskaźniki rozwoju somatycznego dzieci i młodzieży warszawskiej). Med. Wieku Rozwoj 2001: 2 (supl. 1).

20. Kushner RF, Schoeller DA. Estimation of total body water by bioelectrical impedance analysis. Am J ClinNutr 1986: 44: 417-424

21. Rubenstein EB, Peterson DE, Schubert M, Keefe D, McGuire D, Epstein J, et al. Clinical practice guidelines for the prevention and treatment of cancer therapy-induced oral and gastrointestinal mucositis. Cancer 2004; 100: 2026-2046

22. Gosselin KB, Feldman HA, Sonis AL, Bechard LJ, Kellog EM, et al. Serum citrulline as a biomarker of gastrointestinal function during hematopoietic cell transplantation (HCT) in children. J Pediatr Gastroenterol Nutr 2014; 58: 709-714.

23. Crenn P, Messing B, Cynober L. Citrulline as a biomarker of intestinal failure due to enterocyte mass reduction. Clin Nutr 2008; 27:328-339.

24. Rabier D, Kamoun P. Metabolism of citrulline in man. Amino Acids 1995; 9: 299-316.

25. Markan KR, Naber MC, Ameka MK, Anderegg MD, Mangelsdorf DJ, Kliewer SA, et al. Circulating FGF21 is liver derived and enhances glucose uptake during refeeding and overfeeding. Diabetes 63; 12 : 4057-63.

26. Huda MS, Wilding JP, Pinkney JH. Gut peptides and the regulation of appetite. Obes Rev 2006; 7: 16382. 
27. Karaca F, Afsar CU, Gunaldi M, Erkurt E, Ercolak V, Sertdemir Y, et al. Alterations of ghrelin with weights and correlation among ghrelin, cytokine and survival in patients receiving chemoradiotherapy for gastrointestinal cancers. Int J Clin Exp Med 2015; 8: 876-882.

28. Wang Z, Yang WL, Jacob A, Aziz M, Wang P. Human Ghrelin Mitigates Intestinal Injury and Mortality after Whole Body Irradiation in Rats. PLoS One 2015; 10: e0118213.

29. Miyamoto S, Shikata K, Miyasaka K, Okada S, Sasaki M, Kodera R, et al. Cholecystokinin plays a novel protective role in diabetic kidney through anti-inflammatory actions on macrophage: anti-inflammatory effect of cholecystokinin. Diabetes 2012; 61: 897-907.

30. Han Y, Su C, Yu D, Zhou S, Song X, Liu S, et al. Cholecystokinin attenuates radiation-induced lung cancer cell apoptosis by modulating p53 gene transcription. Am J Transl Res 2017; 15: 638-646.

31. Yang C, Lu W, Lin T, You P, Ye M, Huang Y, et al. Activation of Liver FGF21 in hepatocarcinogenesis and during hepatic stress. BMC Gastroenterol 2013; 17: 67.

\section{Tables}

Table 1. Indications for HSCT (pre-HSCT group)

\begin{tabular}{lc} 
Diagnosis & Number ( \%) \\
\hline Acute lymphoblastic leukemia (ALL) & $11(40.7)$ \\
\hline Acute myeloblastic leukemia (AML) & $4(14.8)$ \\
\hline Chronic myelocytic leukemia (CML) & $1(3.6)$ \\
\hline Myelodysplastic syndrome (MDS) & $1(3.6)$ \\
\hline Juvenile myelomonocytic leukemia (JMML) and AML & $1(3.6)$ \\
\hline Neoplastic diseases - total & $18(70)$ \\
\hline Severe aplastic anemia (SAA) & $4(14.8)$ \\
\hline Chronic granulomatous disease (CGD) & $3(8)$ \\
\hline Autoimmune lymphoproliferative syndrome (ALPS) & $1(3.6)$ \\
\hline Hyper IgM syndrome (HIgM) & $1(3.6)$ \\
\hline Non-neoplastic diseases - total & $9(30)$
\end{tabular}

Table 2. Types of HSCT procedures 


\begin{tabular}{|c|c|c|}
\hline Type of HSCT & n (\%) & Disease (n) \\
\hline Allogeneic & MUD - 16 (59) & ALL - 8 \\
\hline \multirow[t]{12}{*}{$\mathrm{n}=27(100 \%)$} & & AML - 4 \\
\hline & & CML - 1 \\
\hline & & SAA - 1 \\
\hline & & CGD - 2 \\
\hline & MSD - 9 (33) & ALL - 3 \\
\hline & & SAA - 2 \\
\hline & & JMML and AML - 1 \\
\hline & & CGD - 1 \\
\hline & & HIgM - 1 \\
\hline & & MDS - 1 \\
\hline & MFD - 2 (8) & $\mathrm{SAA}-1$ \\
\hline & & ALPS - 1 \\
\hline
\end{tabular}

ALL -acute lymphoblastic leukemia

ALPS - autoimmune lymphoproliferative syndrome

AML -acute myeloblastic leukemia

CGD -chronic granulomatous disease

CML-chronic myelocytic leukemia

HIgM- hyper IgM syndrome

JMML -juvenile myelomonocytic leukemia

MDS - myelodysplastic syndrome

SAA -severe aplastic anemia

Table 3. Characteristics of HSCT recipients 
ince diagnosis (years)

oplastic diseases

Median-1, mean-2; range 0.1

n-neoplastic diseases $-7$

Median-1.5, mean-3.8, range $0.1-13$

ioning regimen based on busulfan or treosulfan, $n$ $16(60 \%)$

ody irradiation - 12Gy/6fractions, n (n \%)

$7(26 \%)$

prophylaxis, $\mathrm{n}$ (n \%)

;A

$4(15 \%)$

TX+CSA

$23(85 \%)$

itis, n (\%)

$22(82 \%)$

ade, $\mathrm{n}$

I-7, II-8, III-6, IV-1

эnous alimentation due to mucositis (\%) 48

), n (n \%) $11(41)$

ıcalisation, \%

Gut-9, Skin-91, Liver-27

ade, $\mathrm{n}$

IA-1, IB-4, IIB-1, IIC-3, IIIC-2

nic glucocorticoid treatment, $\mathrm{n}(\%)$ $19(70)$

nic glucocorticoid treatment (days)

Median-3.5, mean-3.6; range $0.1-11$

rom discontinuation of systemic glucocorticoids to the second iment (months)

Median-3.6, mean-4.5; range $0.5-14$

rom discontinuation of immunosuppressive treatment to the second ment (months)

Median 1.6; range 0 - 9

rom HSCT to the second assessment (months)

Median 6.3 (5.9-19.1)

aGvHD - acute graft-versus-host disease, CSA- cyclosporin, MTX - methotrexate

Table 4. Comparison of median parameters of genes expression of peptides regulating gastrointestinal tract 
Gene Gene locus Affimetrix code $\quad$ Expression B-H

\begin{tabular}{|c|c|c|c|c|c|}
\hline \multirow[t]{2}{*}{ Ghrelin } & \multirow[t]{2}{*}{ 3p26-p25 } & \multirow[t]{2}{*}{8085293} & post-HSCT & \multicolumn{2}{|l|}{ Control } \\
\hline & & & $6.84 \pm 0.41$ & $6.99 \pm 0.25$ & $0.07 / 0.09$ \\
\hline \multirow[t]{2}{*}{ Cholecystocinin } & 3p22-p21.3 & 8086391 & post-HSCT & Control & \\
\hline & & & $5.61 \pm 0.14$ & $5.89 \pm 0.23$ & $0.0014 / 0.003$ \\
\hline \multirow[t]{2}{*}{ GLP-1 receptor } & $6 p 21$ & 8119338 & post-HSCT & Control & \\
\hline & & & $6.26 \pm 0.08$ & $6.61 \pm 0.27$ & $0.0000 / 0.0001$ \\
\hline \multirow[t]{4}{*}{ FGF-21 } & 19q13.1-qter & 8030105 & pre-HSCT & Control & \\
\hline & & & $5.46 \pm 0.15$ & $5.59 \pm 0.16$ & $0.0395 / 0.4325$ \\
\hline & & & post-HSCT & Control & $0.0009 / 0.0021$ \\
\hline & & & $5.36 \pm 0.12$ & $5.59 \pm 0.16$ & \\
\hline
\end{tabular}

B-H - Benjamini-Hochberg-corrected P value

Table 5. Values of adipose tissue parameters in studied groups and control.

\begin{tabular}{|c|c|c|c|c|c|c|}
\hline Parameter & pre-HSCT & post-HSCT & Control & $\begin{array}{c}\text { P value, pre-HSCT vs post- } \\
\text { HSCT }\end{array}$ & $\begin{array}{c}\text { P value, } \\
\text { pre-HSCT vs } \\
\text { control }\end{array}$ & $\begin{array}{c}\text { P value, } \\
\text { Post- } \\
\text { HSCT } \\
\text { vs } \\
\text { control }\end{array}$ \\
\hline$\overline{\mathrm{BMI} *}$ & $\begin{array}{c}18.9 \\
(3.33)\end{array}$ & $\begin{array}{r}18.3 \\
(3.47)\end{array}$ & $\begin{array}{r}19.1 \\
(3.00)\end{array}$ & 0.173 & 0.794 & 0.405 \\
\hline BMIPerc** & $\begin{array}{c}70.4 \\
{[44.9 ; 86.4]} \\
\end{array}$ & $\begin{array}{c}51.0 \\
{[16.2 ; 90.6]} \\
\end{array}$ & $\begin{array}{c}77.7 \\
{[46.7 ; 84.3]} \\
\end{array}$ & 0.170 & 0.967 & 0.486 \\
\hline$\overline{\text { BMISDS* }}$ & $0.57(1.21)$ & $0.37(1.26)$ & $0.61(0.87)$ & 0.392 & 0.898 & 0.455 \\
\hline$\overline{\text { BF_kg* }}$ & $6.46(6.42)$ & $6.65(5.35)$ & $12.0(8.46)$ & 0.854 & 0.031 & 0.029 \\
\hline$\overline{\mathrm{BF} \_\% *}$ & $14.5(11.0)$ & $15.8(8.71)$ & $21.1(8.54)$ & 0.616 & 0.042 & 0.062 \\
\hline
\end{tabular}

*Mean values (standard deviations)

**Medians [first and third quartile] 
Figures
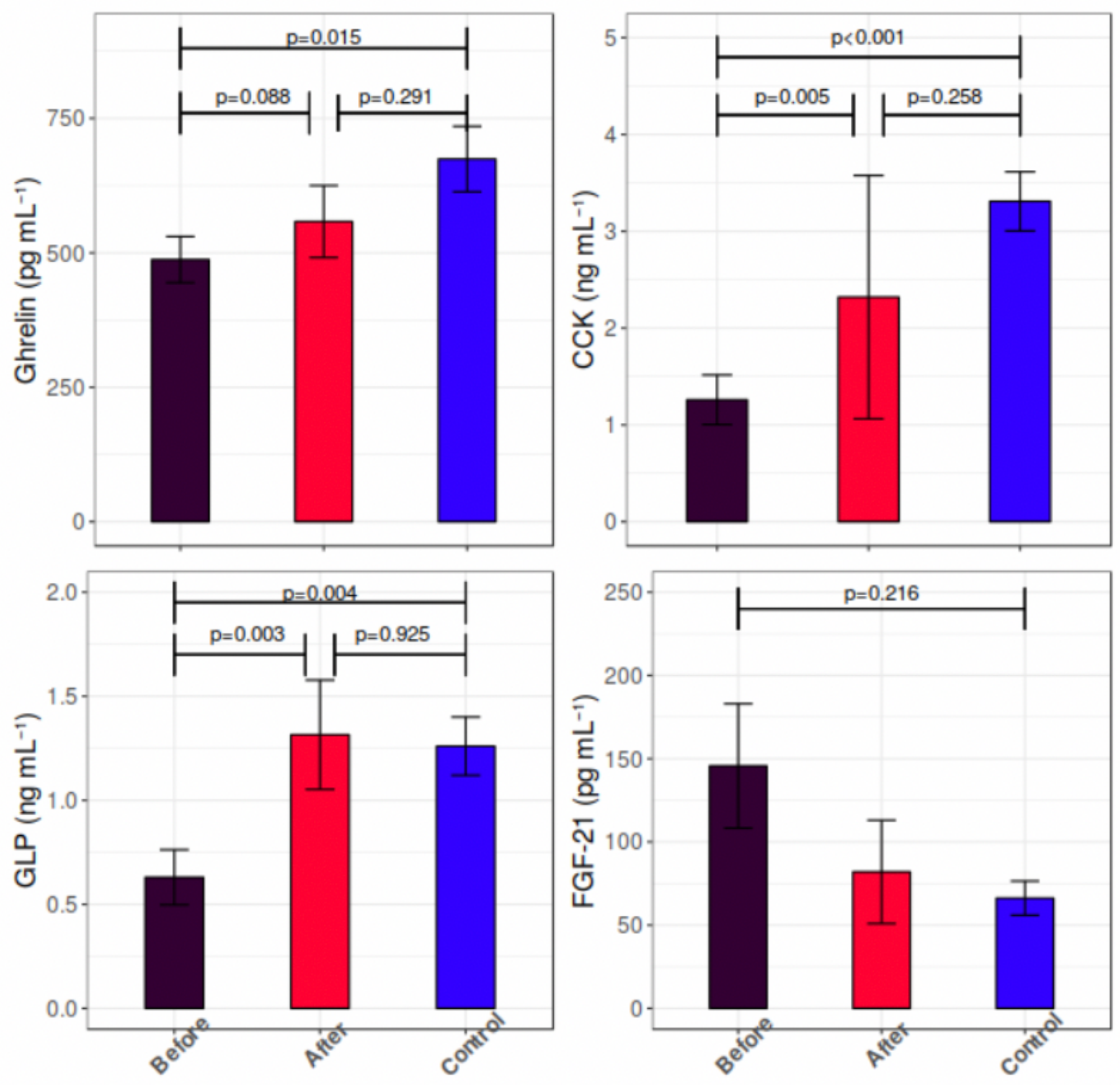

Figure 1

Median concentrations (with standard error) of the peptides going from left up: Ghrelin, Cholecystocinin (CCK), Glucagon like peptide-1 (GLP-1), Fibroblast growth factor-21 (FGF-21). 


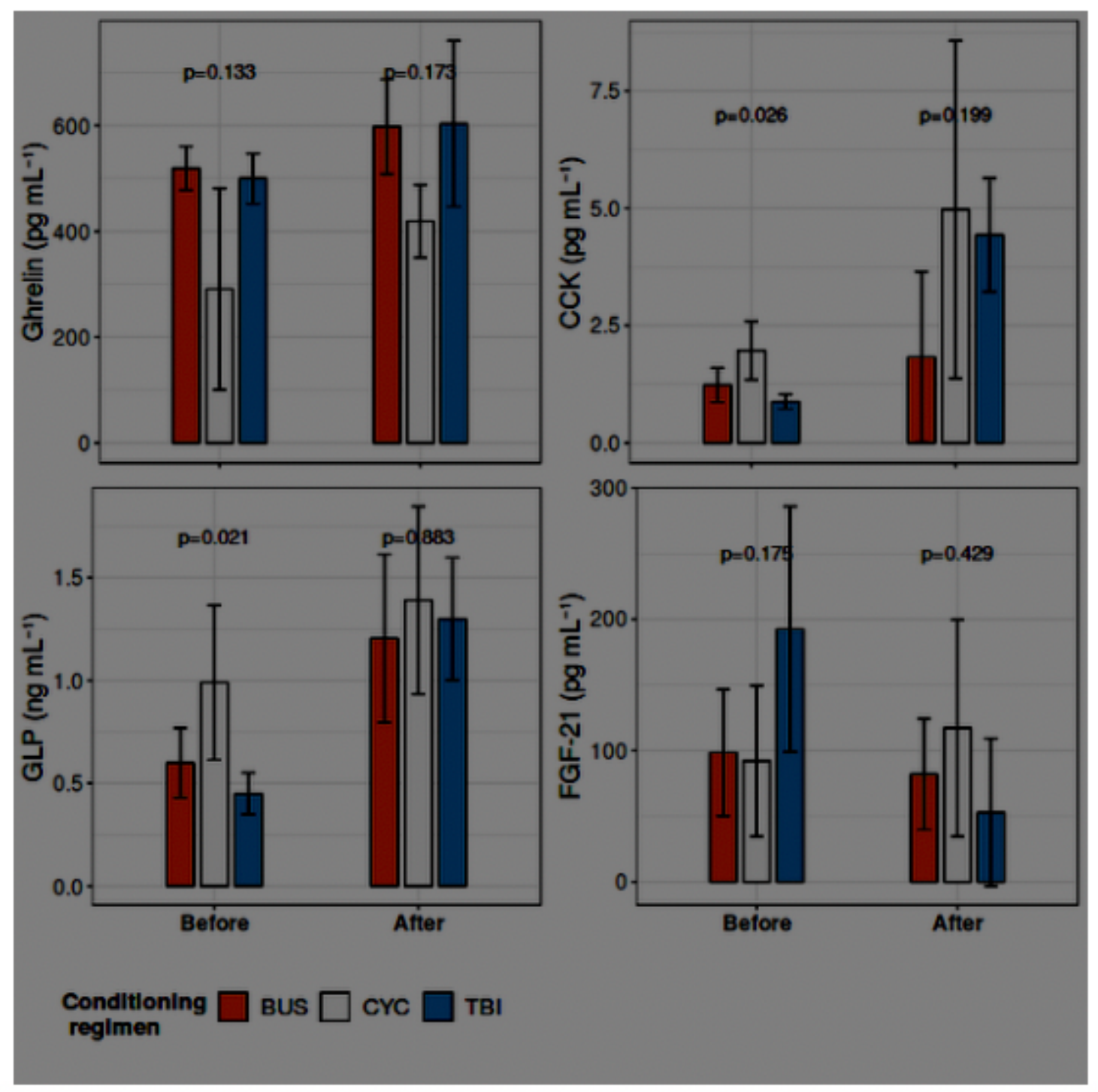

Figure 2 